\title{
Keyakinan Hukum Karma Memoderasi Pengaruh Hedonisme Pada Kecurangan Dalam Pelaporan Keuangan
}

\author{
Anak Agung Tri Megawati ${ }^{1}$ \\ ${ }^{1}$ Fakultas Ekonomi dan Bisnis Universitas Udayana, Indonesia \\ Surel : agungmega8@gmail.com
}

\begin{abstract}
ABSTRAK
Penelitian bertujuan menguji pengaruh hedonisme terhadap kecurangan pelaporan keuangan dan keyakinan hukum karma sebagai variabel moderasi pengaruh hedonisme terhadap kecurangan. Jenis penelitian adalah kuantitatif. Penelitian dilakukan pada Lembaga Perkreditan Desa di Kota Denpasar dengan menggunakan data primer yang diperoleh dengan menyebar kuesioner. Metode penentuan sampel menggunakan metode jenuh dan diperoleh sebanyak 105 responden. Teknik Analisis data yang digunakan adalah uji interaksi variabel moderating Moderated Regression Analysis (MRA). Berdasarkan hasil analisis menunjukkan hedonisme berpengaruh negatif terhadap kecurangan pelaporan keuangan. Hasil penelitian mengindikasikan bahwa hedonisme yang tinggi pada seseorang individu dapat menurunkan terjadinya sebuah kecurangan dalam pelaporan keuangan. Keyakinan hukum karma memoderasi pengaruh hedonisme terhadap kecurangan bahwa keyakinan hukum karma memperlemah pengaruh hedonisme terhadap kecurangan dalam pelaporan keuangan.
\end{abstract}

Kata Kunci: Hedonisme; Keyakinan Hukum Karma; Kecurangan Pelaporan Keuangan.

\section{Belief in the Law of Karma Moderates the Effect of Hedonism on Fraud in Financial Reporting}

\section{ABSTRACT}

This study aims to examine the effect of hedonism on fraudulent financial reporting and the belief in the law of karma as a moderating variable of the effect of hedonism on fraud. This type of research is quantitative. The research was conducted at the Village Credit Institution in Denpasar City using primary data obtained by distributing questionnaires. The method of determining the sample using the saturated method and obtained as many as 105 respondents. The data analysis technique used is the interaction test of the moderating variable Moderated Regression Analysis (MRA). Based on the results of the analysis, it shows that hedonism has a negative effect on fraudulent financial reporting. The results of the study indicate that high hedonism in an individual can reduce the occurrence of fraud in financial reporting. The belief in the law of karma moderates the effect of hedonism on fraud that the belief in the law of karma weakens the influence of hedonism on fraud in financial reporting.

Keywords: Hedonism; Belief in the Law of Karma; Financial Reporting Fraud.

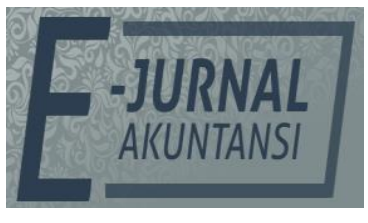

e-ISSN 2302-8556

Vol. 32 No. 2

Denpasar, Februari 2022

Hal. 356-370

DOI:

10.24843/EJA.2020.v32.i02.p06

PENGUTIPAN:

Megawati, A. A. T. (2020).

Keyakinan Hukum Karma Memoderasi Pengaruh

Hedonisme Pada

Kecurangan Dalam

Pelaporan Keuangan.

E-Jurnal Akuntansi, $32(2), 356-370$

RIWAYAT ARTIKEL:

Artikel Masuk:

29 November 2021

Artikel Diterima: 20 Januari

Artikel dapat diakses : https:/ / ojs.unud.ac.id/index.php/Akuntansi/index 


\section{PENDAHULUAN}

Kecurangan (fraud) telah mendapat banyak perhatian publik sebagai dinamika yang menjadi pusat perhatian para pelaku bisnis di dunia. Kecurangan merupakan bentuk penipuan yang sengaja dilakukan sehingga dapat menimbulkan kerugian di banyak pihak. Berdasarkan statement of auditing standart No.99 dalam Norbarani (2012) mendefinisikan kecurangan sebagai tindakan kesengajaan untuk menghasilkan salah saji material dalam laporan keuangan yang merupakan subyek audit. Adinda (2015) mengungkapkan bahwa kecurangan adalah perbuatan-perbuatan yang melawan hukum yang dilakukan dengan sengaja untuk tujuan tertentu (manipulasi, atau memberikan laporan keliru terhadap pihak lain) dilakukan orang-orang dari dalam atau luar organisasi untuk mendapatkan keuntungan pibadi atau kelompok secara langsung atau tidak langsung merugikan pihak lain.

Association of Certified Fraud Examiners (ACFE) membagi kecurangan kedalam tiga jenis atau tipologi perbuatan. Pertama, penyimpangan aset, yang kedua pernyataan palsu/kecurangan laporan keuangan dan yang terakhir korupsi. Penyimpangan aset yang meliputi penyalahgunaan/ pencurian aset atau harta perusahaan atau pihak lain. Bentuk kecurangan ini paling mudah dideteksi karena bersifat tangible atau dapat diukur dan dihitung. Jenis kecurangan yang kedua berupa pernyataan palsu/kecurangan laporan keuangan yang meliputi tindakan yang dilakukan oleh pejabat atau eksekutif suatu perusahaan atau instansi pemerintah untuk menutupi kondisi keuangan yang sebenarnya dengan melakukan rekayasa keuangan dalam penyajian laporan keuangannya untuk memperoleh keuntungan. Jenis kecurangan yang terakhir yaitu korupsi merupakan jenis kecurangan yang paling sulit untuk dideteksi, karena menyangkut kerjasama dengan pihak lain. Kecurangan jenis ini seringkali tidak dapat dideteksi karena para pihak yang bekerja sama menikmati keuntungan, termasuk didalamnya penyalahgunaan wewenang/konfilk kepentingan. Kecurangan tersebut dapat terjadi di berbagai Lembaga keuangan termasuk Lembaga keuangan nonbank seperti LPD.

LPD merupakan lembaga keuangan milik desa pekraman yang bertempat di wilayah desa pekraman. Berdasarkan Peraturan Daerah Provinsi Bali Nomor 3 Tahun 2017 tentang Lembaga Perkreditan Desa menyatakan bahwa Lembaga Perkreditan Desa diperlukan keberadaannya untuk menjamin perwujudan kesejahteraan masyarakat hukum adat yang merupakan Krama Desa Pakraman. LPD melaksanakan kegiatan operasional usaha di lingkungan desa dan untuk Krama Desa. Sangat pentingnya peranan LPD bagi masyarakat desa pekraman membuat tindakan yang dilakukan oleh Kepala LPD menjadi sorotan masyarakat karena Kepala LPD merupakan pembuat keputusan terkait aktivitas yang berkaitan dengan LPD. Suartana (2016) juga menyatakan berbagai persoalan yang muncul di LPD seperti adanya pengurus LPD yang kena kasus pidana akibat kecurangan atau hal - hal yang menjurus fraud dan kesalahan administratif mengakibatkan kredit macet yang berujung kepercayaan yang meluntur. Bahaya risiko usaha LPD tersebut nampaknya merupakan ciri dari risiko bawaan yang bisa menimpa semua organisasi tanpa kecuali. Risiko bawaan ini bisa berkurang bila ada pengawasan yang kuat, sikap etis dan taat pimpinannya. 
Report to the nation on occupational fraud and abuse pada tahun 2012 menyebutkan industri-industri yang paling umum dan sering menjadi korban kecurangan adalah jasa keuangan dan perbankan, administrasi publik, dan manufaktur. Salah satu lembaga yang rentan terhadap kecendrungan kecurangan dalam pelaporan keuangan yaitu Lembaga Perkreditan Desa (LPD) Kasus mengenai kecurangan dalam pelaporan keuangan yang menimpa Indonesia tidak hanya terjadi pada kota - kota besar, korupsi juga mulai masuk ke dalam desa. Sebagai contoh berita yang dimuat oleh Radar Bali, 17 januari 2020 di daerah Singaraja Provinsi Bali terdapat tindakan kecurangan tindak pidana korupsi kredit tidak benar (fiktif) senilai Rp 1,2 miliar yang terjadi di LPD Gerokgak (Mustofa, 2020), dimana Penyidik Kejaksaan Tinggi (Kejati) Bali akhirnya melimpahkan perkara penanangan kasus dugaan penyelewengan dana lembaga perkreditan desa (LPD) Gerokgak kepada jaksa penuntut umum (JPU) Kejaksaan Negeri (Kejari Buleleng). Pelimpahan perkara tahap II kasus LPD Gerokgak yang menyeret mantan Ketua LPD Gerokgak.

Perilaku menyimpang seperti kecurangan dalam pelaporan keuangan dalam kehidupan sehari-hari dapat diminimalisasi dengan adanya nilai-nilai etika. Nilai-nilai dan moral pribadi perorangan dan konteks social menentukan apakah suatu perilaku tertentu dianggap sebagai perilaku yang etis atau tidak etis. Kecurangan khususnya kecurangan dalam pelaporan keuangan dipengaruhi oleh beberapa faktor, salah satunya adalah hedonisme (Utama et al., 2018; Himmah (2013). Nadzir dan Ingarianti (2015) menyatakan hedonisme memiliki pandangan hidup yang menganggap bahwa orang akan menjadi bahagia dengan mencari kebahagiaan sebanyak mungkin dan sedapat mungkin menghindari perasaan yang menyakitkan. Hal ini ditunjukkan dengan banyaknya orang yang memilih model pakaian, tas dan barang-barang dengan merk terkenal, menggunakan handphone dengan fasilitas layanan terbaru, berbelanja di pusat perbelanjaan modern dan jalan-jalan untuk sekedar mengisi waktu luang. Orang yang terjebak dalam gaya hidup hedonisme akan mengambil sisi kehidupan yang menyenangkan saja, sementara hal yang dianggap menyengsarakan dihindari. Berdasarkan kasus-kasus yang terjadi perilaku hedonism memiliki kecenderungan mengarahkan ke sikap hedonisme yang akan memicu terjadinya kecurangan. Shonhadji \& Maulidi (2021); Smaili et al., (2021); Sallal et al., (2021); Dempere (2021); Prastika (2018) menemukan bahwa gaya hidup hedonisme berpengaruh positif terhadap kecurangan akademik. Penelitian serupa juga dilakukan oleh Sartika \& Hudainah (2018) yang menemukan bahwa gaya hidup hedonis berpengaruh positif terhadap intensi korupsi.

Pada Fraud Triangle Theory, hedonisme berkaitan dengan tekanan (pressure) dan peluang (opportunity). Pressure adalah dorongan orang untuk melakukan fraud, dan opportunity adalah peluang yang memungkinkan terjadinya fraud. Tekanan dan peluang dapat mencakup hampir semua hal termasuk gaya hidup, tuntutan ekonomi, dan lain - lain termasuk hal keuangan dan nonkeuangan. Ketika tindakan fraud telah terdeteksi, biasanya pelaku akan memberikan alasan yang rasional sebagai bentuk pembelaan diri. Rasionalisasi ini terjadi untuk menjadikan kesalahan yang terjadi adalah tindakan yang wajar dilakukan Seseorang akan melakukan tindak kecurangan jika ada dorongan atau motivasi dalam dirinya, salah satu dorongan tersebut yaitu gaya hidup. Seperti yang 
diungkapkan Utama et al.,(2018), salah satu contoh dari pressure yaitu dorongan untuk memiliki barang - barang yang bersifat materi. Kennedy (2018), Rostami \& Rezaei (2021), Liu et al. (2021), Roszkowska (2021), Schmidt et al. (2021), dan Himmah (2013) juga menyatakan bahwa karakteristik pribadi yang individual, materialis dan kapitalis mendorong orang untuk melakukan hal yang negatif tanpa memikirkan dampak atas perbuatan tersebut, salah satunya adalah melakukan kecurangan (fraud) atau perilaku tidak etis. Berdasarkan fraud triangle theory yang dimana dapat mendeteksi kecurangan dari seorang pekerja, terdapat hukum karma yang sering dikenal oleh masyarakat, yang dimana hukum karma ini sering dijadikan landasan bagi beberapa individu dalam bertindak.

Penelitian ini menggunakan variabel keyakinan hukum karma sebagai pemoderasi, karena konsep hedonisme yang berkaitan dengan gaya hidup yang berlebihan dengan melakukan berbagai cara untuk memenuhi kebutuhannya, apabila didukung oleh keyakinan hukum karma tentu akan mempengaruhi seseorang dalam melakukan tindakan kecurangan dalam pelaporan keuangan. Sehingga ketika perilaku hedonisme yang berada dalam diri seseorang tinggi namun ketika seseorang memiliki keyakinan hukum karma dapat menekan seseorang untuk tidak melakukan tindakan kecurangan khususnya dalam penelitian ini yaitu pada LPD. Pada penelitian ini, ajaran nilai dan perilaku yang terdapat dalam keyakinan hukum karma diharapkan memperlemah faktor-faktor internal individu yaitu hedonisme dan kecurangan.

Hukum karma adalah keyakinan yang dimiliki dan menjadi dasar kehidupan masyarakat Bali. Istilah karma secara harfiah berarti tindakan, pekerjaan atau perbuatan. Segala jenis tindakan yang disengaja baik mental, verbal atau fisik, dianggap sebagai karma. Ini mencakup semua dalam frase baik pemikiran, perkataan dan perbuatan. Menurut hukum karma, tindakan individu dan kolektif menentukan sifat keberadaan di masa kehidupan sekarang atau di masa depan. Semua yang kita lakukan, katakan atau pikirkan, yang akan menimbulkan efek dan pada waktunya akan kembali kepada kita (Asri, 2018). Seseorang yang memiliki keyakinan ini diharapkan dapat memperbaiki moral dan etika manusia dalam kehidupan bermasyarakat, dengan memahami hakekat tentang hukum karma maka manusia tidak akan melakukan perbuatan-perbuatan tercela dan menyebabkan kerugian atau kehancuran bagi orang lain (Munidewi, 2017). Ini juga didukung oleh penelitian Chadha et al., (2013) yang memaparkan bahwa konsekuensi logis dari etika hukum karma adalah untuk berperilaku secara bertanggung jawab.

Penelitian ini dilakukan untuk mendeteksi apakah hedonisme merupakan faktor yang mempengaruhi kecurangan kecurangan dalam pelaporan keuangan di LPD Kota Denpasar dengan memasukkan variabel keyakinan hukum karma sebagai variabel moderasi sehingga penelitian ini relatif baru. Perilaku hedonism ini identic dengan adanya kecurangan karena jika seseorang telah memiliki sikap hedonisme dan sudah menjadi ketergantungan dengan gaya hidup hedonisme, maka cenderung dapat mengarahkan ke tindak kecurangan, LPD dipilih karena LPD adalah Lembaga keuangan yang cakupannya lebih kecil dan lebih dekat dengan masyarakat. Berdasarkan latar belakang penelitian tersebut, penelitian ini menguji pengaruh hedonisme terhadap kecurangan LPD Kota Denpasar dengan hukum karma sebagai variabel pemoderasi. 
Konsep kecurangan dalam pelaporan keuangan didasarkan pada model fraud triangle Aviantara (2021), Dashtbayaz et al. (2022), Akgun (2021), Orth \& Macada (2021), dan Lee \& Ha (2021) . Fraud triangle menjelaskan tiga faktor yang hadir dalam setiap situasi fraud berupa faktor - faktor yang mempengaruhi seseorang melakukan kecurangan. Secara umum kecurangan mempunyai tiga sifat yang diungkapkan dalam fraud triangle yaitu tekanan (Pressure) adalah dorongan orang untuk melakukan fraud, peluang (Opportunity) adalah peluang yang memungkinkan terjadinya kecurangan, dan rasionalisasi (Rationalization) adalah mencari pembenaran secara rasional untuk membenarkan perbuatanya.

Pengaruh hedonisme terhadap kecurangan dalam pelaporan keuangan didasari dari Theory of Planned Behavior (TPB) merupakan niat individu untuk melaksanakan perilaku tertentu. Niat diasumsikan untuk menangkap faktor motivasi yang mempengaruhi perilaku, yang mengindikasikan seberapa kuat keinginan orang untuk mencoba, atau seberapa besar usaha yang dilakukan dalam rangka melaksanakan suatu perilaku yaitu perilaku melakukan kecurangan dalam pelaporan keuangan.

Hedonisme merupakan suatu pola hidup seseorang yang melakukan aktivitasnya untuk mencari kesenangan hidup, menghabiskan waktunya diluar rumah untuk bersenang-senang dengan temannya, gemar membeli barang yang tidak dibutuhkan, serta selalu ingin menjadi pusat perhatian di lingkungan sekitarnya. Jika seseorang atau individu memiliki sifat hedonisme dapat menyebabkan seseorang akan melakukan tindak kecurangan. kecurangan dalam pelaporan keuangan merupakan suatu perbuatan melawan hukum yang dilakukan orang-orang baik dari dan atau luar organisasi yang dimaksudkan untuk memperoleh keuntungan pribadi atau kelompoknya yang dapat merugikan pihak lainnya. Tindakan tersebut dilakukan dengan kesengajaan baik secara spontan maupun direncanakan

Berdasarkan penelitian penelitian sebelumnya yang dilakukan oleh Prastika (2018) menunjukkan bahwa terdapat pengaruh positif gaya hidup hedonisme terhadap kecurangan akademik pada mahasiswa. Sartika \& Hudainah (2018) menunjukkan adanya hubungan positif antara gaya hidup hedonisme dengan intense korupsi pada mahasiswa pengurus lembaga intra. Blickle et al., (2006) memperoleh hasil prilaku hedonisme berpengaruh terhadap pelanggaran ekonomi, dan Price \& Norris (2009) memperoleh hasil para pelaku bisnis melakukan kejahatan kerah putih karena mengejar kepentingan pribadi yaitu memiliki prilaku hedonisme. Berdasarkan uraian penjelasan di atas dapat ditarik hipotesis sebagai berikut.

$\mathrm{H}_{1}$ : Hedonisme berpengaruh positif terhadap kecurangan dalam pelaporan keuangan.

Konsep kecurangan dalam pelaporan keuangan didasarkan pada model fraud triangle. Fraud triangle menjelaskan tiga faktor yang hadir dalam setiap situasi fraud berupa faktor - faktor yang mempengaruhi seseorang melakukan kecurangan Rostami \& Rezaei (2021), Ozcelik (2020), Lotfi et al., (2021), Awang \& Ismail (2018). Secara umum kecurangan mempunyai tiga sifat yang diungkapkan dalam fraud triangle yaitu tekanan (Pressure) adalah dorongan orang untuk melakukan fraud, peluang (Opportunity) adalah peluang yang memungkinkan 
terjadinya kecurangan, dan rasionalisasi (Rationalization) adalah mencari pembenaran secara rasional untuk membenarkan perbuatanya.

Keyakinan hukum karma memoderasi pengaruh hedonisme terhadap kecurangan dalam pelaporan keuangan didasarkan pada Theory of Planned Behavior (TPB), dimana merupakan niat individu untuk melaksanakan perilaku tertentu. Niat diasumsikan untuk menangkap faktor motivasi yang mempengaruhi perilaku, yang mengindikasikan seberapa kuat keinginan orang untuk mencoba, atau seberapa besar usaha yang dilakukan dalam rangka melaksanakan suatu perilaku yaitu perilaku melakukan kecurangan dalam pelaporan keuangan.

Hukum karma adalah keyakinan yang dimiliki dan menjadi dasar kehidupan. Menurut hukum karma, tindakan individu dan kolektif menentukan sifat keberadaan di masa kehidupan sekarang atau di masa depan. Semua yang kita lakukan, katakan atau pikirkan, yang akan menimbulkan efek dan pada waktunya akan kembali kepada kita. Filosofi karma mengajarkan kepada kita, tidak sekedar memperhatikan tindakan, tetapi juga pikiran dan emosi kita. Dengan memahami hakekat tentang hukum karma, maka manusia atau individu yang memiliki sifat hedonisme tidak akan mungkin untuk melakukan perbuatanperbuatan tercela seperti melakukan kecurangan dalam pelaporan keuangan yang jelas keluar dari ajaran agama dan menyebabkan kerugian atau kehancuran bagi oranglain.

Berdasarkan penelitian penelitian sebelumnya yang dilakukan oleh Chadha et al., (2013) memaparkan bahwa optimism dan kepercayaan pada hukum karma akan berhubungan positif dengan kepemimpinan transformasional. Asri (2018) menyatakan keyakinan hukum karma dapat memperkuat pengaruh negatif sistem perpajakan pada persepsi penggelapan pajak. Chakraborty (2014) menyatakan bahwa Seluruh hidup berpusat pada karma, tidak ada yang hidup tanpa melakukan karma, karena keputusan dan tindakan itu menghasilkan karma. Hilderbrand (2018) menyatakan bahwa karma adalah kepastian utama kehidupan dan terkait dengan kebahagiaan. Dariuraian di atas, maka dapat dirumuskan hipotesis sebagai berikut.

$\mathrm{H}_{2}$ : Keyakinan Hukum Karma memperlemah pengaruh Hedonisme terhadap kecurangan dalam pelaporan keuangan.

\section{METODE PENELITIAN}

Penelitian ini merupakan penelitian kuantitatif. Pengumpulan data dilakukan dengan metode dokumentasi dan kuesioner. Populasi yang digunakan dalam penelitian ini adalah LPD yang ada di Kota Denpasar. Teknik penentuan sampel yang digunakan adalah dengan teknik sampel jenuh, dimana seluruh dari populasi dijadikan sebagai sampel. Teknik analisis yang dipergunakan untuk menganalisis data adalah analisis regresi linear sederhana dan untuk menguji regresi dengan variabel pemoderasi menggunakan Moderated Regression Analysis (MRA). Penelitian ini dilakukan pada Lembaga Perkreditan Desa (LPD) yang terdapat di kota Denpasar. Jumlah LPD yang berada di Kota Denpasar adalah sebanyak 35 (tiga puluh lima) yang tersebar di 4 kecamatan yaitu Denpasar Selatan, Denpasar Utara, Denpasar Timur dan Denpasar Barat. Waktu penelitian yaitu pada tahun 2020 . 
Berikut ini adalah penjelasan mengenai definisi operasional variabel yang digunakan dalam penelitian ini, yang pertama adalah kecurangan dalam pelaporan keuangan. Menurut SA 240 No 11, kecurangan dalam pelaporan keuangan adalah suatu tindakan yang disengaja oleh satu individu atau lebih dalam manajemen, pihak yang bertanggungjawab atas tata kelola, karyawan, atau pihak ketiga, yang melibatkan penggunaan tipu muslihat untuk memperoleh suatu keuntungan secara tidak adil atau melanggar hukum. Variabel ini diukur dengan kuesioner dengan menggunakan 5 skala likert, dimana dimensi yang digunakan diadopsi dari penelitian (Achmad, 2019) Adapun indikator dari variabel tersebut adalah memperkecil biaya yang dicatat, memperbesar catatan pendapatan, perilaku kecurangan dilakukan dengan nia, pelaku kecurangan berusaha untuk menutupi kecurangannya.

Kedua, Hedonisme adalah sebuah pandangan bahwa kesenangan merupakan tujuan utama dalam hidupnya serta selalu menghindari kesengsaraan dengan melakukan berbagai cara. Sedangkan gaya hidup hedonisme adalah suatu pola hidup khas dari sikap, cara dan pola tindakan untuk mencapai tujuan, konsep diri dan perasaan yang mengarah pada keinginan untuk mengejar kesenangan dan diungkapkan dalam aktivitas, minat dan pendapat dengan menghalalkan berbagai cara. Variabel ini diukur dengan menggunakan 5 skala likert, dimana dimensi yang digunakan diadopsi dari penelitian (Prastika, 2018). Adapun indikator dari variabel tersebut adalah attitudes, sikap dalam mencapai kepuasan, manners, cara individu memeroleh kepuasan, Action, tindakan yang dilakukan untuk mencapai kepuasan, Activities, kegiatan dalam menghabiskan waktu untuk bersenang-senang, Interests, ketertarikan pada hal-hal dalam memeroleh kesenangan, Opinion, pendapat yang berkaitan dengan hal-hal untuk memeroleh kesenangan.

Ketiga yakni Keyakinan hukum karma adalah kepercayaan pada hukum spiritual yang mengatur pengalaman hidup melalui prinsip sebab akibat, aksi dan reaksi, keadilan dan tanggungjawab pribadi (Chakraborty, 2014). Variabel ini diukur dengan menggunakan 5 skala likert, dimana dimensi yang digunakan diadopsi dari penelitian (Chadha et al., 2013). Adapun indikator dari variabel tersebut adalah Pengalamam merupakan suatu proses pembelajaran dan pertambahan perkembangan potensi untuk berprilaku yang baik. Intelektual merupakan segala sesuatu yang diketahui berkenaan dengan hukum karma. Konsekunsi merupakan hukuman karena melanggar peraturan dan hukum yang berlaku.

Alasan peneliti memilih Denpasar sebagai tempat penelitian dikarenakan peneliti ingin meneliti LPD yang terdapat di kota karena selama ini LPD selalu dikaitkan dengan desa. Alasan lainnya yakni LPD dipilih karena LPD adalah Lembaga keuangan yang dekat dengan masyarakat Bali serta keyakinan masyarakat Bali akan adanya hukum karma. LPD sangat memegang peranan penting bagi masyarakat khususnya di Denpasar yang memiliki pertumbuhan ekonomi yang sangat pesat. Responden dalam penelitian ini adalah seluruh pengurus (kepala, bendahara dan sektretaris) Lembaga Perkreditan Desa (LPD) yang terdapat di kota Denpasar pada tahun 2020. Sampel dalam penelitian ini adalah seluruh anggota populasi yaitu seluruh pengurus (kepala, bendahara dan sektretaris) LPD se-Kota Denpasar. 


\section{HASIL DAN PEMBAHASAN}

Dalam penelitian ini, kuesioner dikirim secara langsung kepada responden. Kuesioner yang digunakan adalah kuesioner yang kembali dan telah diisi secara lengkap oleh responden. Berikut dalam Tabel 1 disajikan distribusi kuesioner dan tingkat pengembalian kuesioner yang dapat diolah.

Tabel 1. Tingkat Pengembalian Kuesioner

\begin{tabular}{lcc}
\hline Keterangan & Jumlah & Persentase \% \\
\hline Jumlah Sampel & 105 & 100 \\
Kuesioner yang dikirimkan & 105 & 100 \\
Kuisioner tidak Kembali & 0 & 0 \\
Kuisioner yang Kembali & 105 & 100 \\
Kuisioner yang tidak dapat diolah & 0 & 0 \\
Kuisioner yang dapat diklasifikasikan & 105 & 100 \\
\hline
\end{tabular}

Sumber: Data Primer diolah (2021)

Pada Tabel 1 menunjukkan bahwa dari 105 kuesioner yang disebar, tingkat pengambilan kuesioner berjumlah $100 \%$. Seluruh kuesioner yang dikembalikan pengisiannya telah lengkap dan memenuhi ketentuan sehingga tidak terdapat kuesioner yang gugur.

Berdasarkan kusioner yang telah disebar, komposisi jenis kelamin laki-laki sebanyak 65 orang $(61,90 \%)$ dan perempuan sebanyak 40 orang (38,10\%). Persentase responden yang berjenis kelamin laki-laki lebih tinggi dibandingkan yang berjenis kelamin perempuan. Penelitian (Venkatesh et al., (2003) memperoleh bukti empiris bahwa terdapat perbedaan orientasi gender antara laki-laki dan perempuan. Pertama, gender laki-laki cenderung pada ekspektansi kinerja yang lebih tinggi daripada gender perempuan. Kedua, gender perempuan cenderung pada ekspektansi usaha yang lebih tinggi daripada gender laki-laki. Ketiga, efek faktor sosial terhadap minat lebih kuat gender perempuan dibanding gender lakilaki. Hal ini mengindikasikan gender laki-laki cenderung memiliki potensi memiliki ekspansi usaha lebih luas dibandingkan dengan gender perempuan, hal ini berarti gender laki-laki lebih memiliki potensi terlibat dalam kasus fraud.

Usia dibawah $<50$ tahun sebanyak 58 orang $(55,23 \%)$ dan diatas $>50$ tahun sebanyak 47 orang (44,77\%). Hal ini mencerminkan pegawai LPD se-Kota Denpasar didominasi usia yang kurang dari 50 tahun atau tergolong usia produktif. Usia produktif cenderung diidentikan dengan individu yang memiliki semangat kerja dan sikap hedonisme, jika pada usia produktif ini kecenderungan individu tersebut memiliki sikap hedonisme maka diindikasikan mudah untuk melakukan fraud.

Sampel yang digunakan sebagai responden memiliki tingkat pendidikan SMA sebanyak 50 orang $(47,61 \%)$, Sarjana Srata S1 sebanyak 51 orang $(48,57 \%)$, Sarjana Srata S2 sebanyak 3 orang $(2,85 \%)$ dan Sarjana Srata S3 sebanyak 1 orang $(0,95 \%)$. Hal ini mencerminkan bahwa sebagian besar responden memiliki tingkat pendidikan yang cukup baik, yang menandakan bahwa responden memiliki pengetahuan dan kompetensi yang cukup baik pula. Pendidikan yang cukup baik belum tentu akan menjauhkan seseorang dari tindakan kecurangan, hal ini dikarenakan banyak kasus dimana seseorang yang terlibat fraud memiliki Pendidikan yang cukup baik. 
Tabel 2. Statistik Deskriptif

\begin{tabular}{|c|c|c|c|c|c|c|c|c|}
\hline & $\mathrm{N}$ & Min. & Max. & Mean & $\begin{array}{c}\text { Std. } \\
\text { Deviation }\end{array}$ & Selisih & $\begin{array}{l}\text { Rata- } \\
\text { rata }\end{array}$ & Kriteria \\
\hline Hedonisme $\left(\mathrm{X}_{1}\right)$ & 105 & 24 & 57 & 40,54 & 8,589 & 33 & 6,6 & $\begin{array}{l}\text { Sangat } \\
\text { Setuju }\end{array}$ \\
\hline $\begin{array}{l}\text { Keyakinan Hukum } \\
\text { Karma }\left(\mathrm{X}_{2}\right)\end{array}$ & 105 & 26 & 35 & 30,20 & 2,177 & 9 & 1,8 & $\begin{array}{l}\text { Tidak } \\
\text { Setuju }\end{array}$ \\
\hline $\begin{array}{l}\text { Kecurangan dalam } \\
\text { pelaporan } \\
\text { keuangan }(\mathrm{Y})\end{array}$ & 105 & 4 & 8 & 6,28 & 1,369 & 4 & 0,8 & $\begin{array}{l}\text { Sangat } \\
\text { Tidak } \\
\text { Setuju }\end{array}$ \\
\hline
\end{tabular}

Sumber: Data Penelitian, 2021

Nilai minimum dari jumlah skor jawaban responden untuk variabel hedonisme sebesar 24 dan nilai tertinggi sebesar 57. Nilai tengah (mean) dari jumlah skor jawaban responden sebesar 40,54, maka jawaban responden dapat dikategorikan sangat setuju. Hal ini menunjukkan kecurangan dalam pelaporan keuangan LPD di Kota Denpasar memiliki respon yang sangat setuju terhadap hedonisme.

Nilai minimum dari jumlah skor jawaban respon untuk variabel keyakinan hukum karma sebesar 26 dan nilai tertinggi sebesar 35. Nilai tengah (mean) dari jumlah skor jawaban responden sebesar 30,20, maka jawaban responden dapat dikategorikan tidak setuju. Hal ini menunjukkan kecurangan dalam pelaporan keuangan LPD di Kota Denpasar memiliki respon yang tidak setuju terhadap keyakinan hukum karma.

Nilai minimum dari jumlah skor jawaban responden untuk variabel kecurangan dalam pelaporan keuangan $(Y)$ sebesar 4 dan nilai tertinggi sebesar 8 . Nilai tengah (mean) dari jumlah skor jawaban responden sebesar 6,28, maka jawaban responden dapat dikategorikan sangat tidak setuju. Hal ini menunjukkan kecurangan dalam pelaporan keuangan LPD di Kota Denpasar memiliki respon yang sangat tidak setuju terhadap kecurangan dalam pelaporan keuangan.

Tabel 3. Hasil Analisis Regresi Moderasi

\begin{tabular}{|c|c|c|c|c|c|}
\hline \multirow[t]{2}{*}{ Model } & \multicolumn{2}{|c|}{$\begin{array}{l}\text { Unstandardized } \\
\text { Coefficients }\end{array}$} & \multirow{2}{*}{$\begin{array}{c}\text { Standardized } \\
\text { Coefficients } \\
\text { Beta }\end{array}$} & \multirow[t]{2}{*}{$\mathrm{T}$} & \multirow[t]{2}{*}{ Sig. } \\
\hline & B & Std. Error & & & \\
\hline 1 (Constant) & 7,478 & 1,621 & & 4,613 & 0,000 \\
\hline Hedonisme $\left(\mathrm{X}_{1}\right)$ & $-0,273$ & 0,035 & $-1,713$ & $-7,741$ & 0,000 \\
\hline $\begin{array}{l}\text { Keyakinan Hukum Karma } \\
\left(\mathrm{X}_{2}\right)\end{array}$ & 0,013 & 0,051 & 0,021 & 0,261 & 0,794 \\
\hline X1.X2 & 0,008 & 0,001 & 1,482 & 6,700 & 0,000 \\
\hline R Square & & & & & 0,409 \\
\hline Adjusted R Square & & & & & 0,391 \\
\hline $\mathrm{F}_{\text {Statistik }}$ & & & & & 23,296 \\
\hline Sig. & & & & & 0,000 \\
\hline
\end{tabular}

Sumber: Data Penelitian, 2021

Berdasarkan Tabel 3, dapat dibuat suatu model persamaa regresi moderasi yaitu sebagai berikut:

$Y=\alpha+\beta_{1} X_{1}+\beta_{2} X_{2}+\beta_{3} X_{1} \cdot X_{2}+\varepsilon$

$Y=7,478-0,273 X_{1}+0,013 X_{2}+0,008 X_{1} \cdot X_{2}$ 
Uji $F\left(F_{\text {test }}\right)$ menunjukkan bahwa nilai signifikansi $P$ value 0,000 yang lebih kecil dari $a=0,05$ ini berarti model yang digunakan pada penelitian ini adalah layak. Hasil ini memberikan makna bahwa seluruh variabel independen yaitu hedonisme $\left(X_{1}\right)$, keyakinan hukum karma $\left(X_{2}\right)$ dan variabel interaksi antara hedonisme dengan keyakinan hukum karma $\left(X_{1} . X_{2}\right)$ mampu mempredikasi atau menjelaskan fenomena kecurangan dalam pelaporan keuangan. Hal ini berarti model dapat digunakan untuk analisa lebih lanjut atau dengan kata lain model dapat digunakan untuk memproyeksikan karena hasil goodness offitnya baik dengan nilai signifikansi $P$ value 0,000 .

Hasil uji memberikan hasil dimana diperoleh besarnya adjusted R2 (koefisien determinasi yang telah disesuaikan) pada Tabel 2. adalah 0,409. Ini berarti variasi kecurangan dalam pelaporan keuangan dapat dipengaruhi secara signifikan oleh variabel hedonisme $\left(X_{1}\right)$, keyakinan hukum karma $\left(X_{2}\right)$, interaksi $X_{1} . X_{2}$ sebesar 40,9 persen, sedangkan sisanya sebesar 59,1 persen dijelaskan oleh faktor-faktor lain yang tidak dijelaskan dalam model penelitian.

Pengaruh Hedonisme terhadap Kecurangan dalam pelaporan keuangan Lembaga Perkreditan Desa (LPD) berdasarkan karakteristik responden menunjukan komposisi jenis kelamin didominasi oleh laki-laki sebanyak 65 orang (61,90 persen), dengan usia lebih banyak dibawah $<50$ tahun sebanyak 58 orang (55,23 persen) dan memiliki tingkat pendidikan terbanyak pada sarjana Srata S1 sebanyak 51 orang (48,57 persen). Hal ini mencerminkan bahwa sebagian besar responden memiliki tingkat pendidikan yang cukup baik, yang menandakan bahwa responden memiliki pengetahuan dan kompetensi yang cukup baik pula sehingga niat untuk melakukan tindakan kecurangan dalam pelaporan keuangan tidak akan terjadi. Berdasarkan bukti empiris diperoleh bahwa $\mathrm{H}_{1}$ di dukung dengan koefisien negatif dengan demikian hipotesis pertama $\mathrm{H}_{1}$ ditolak yaitu, hedonisme berpengaruh negatif terhadap kecurangan dalam pelaporan keuangan. Hasil penelitian ini mengindikasikan bahwa hedonisme yang tinggi pada seseorang individu tidak dapat mempengaruhi terjadinya sebuah kecurangan dalam pelaporan keuangan.

Pengaruh hedonisme terhadap kecurangan didasari dari Theory of Planned Behavior (TPB), dimana Theory of Planned Behavior (TPB) merupakan niat individu untuk melaksanakan perilaku tertentu seperti melakukan tindakan kecurangan dalam pelaporan keuangan. Seseorang individu yang memiliki sifat hedonisme yang tinggi tetapi tidak memiliki niat untuk melakukan tindakan kecurangan dalam pelaporan keuangan, maka tindakan kecurangan tidak akan terjadi. Niat diasumsikan untuk menangkap faktor motivasi yang mempengaruhi perilaku, yang mengindikasikan seberapa kuat keinginan orang untuk mencoba, atau seberapa besar usaha yang dilakukan dalam rangka melaksanakan suatu perilaku yaitu perilaku untuk tidak melakukan kecurangan dalam pelaporan keuangan.

Hasil dari tabulasi data penelitian yang menunjukkan jawaban responden yang tinggi pada kuesioner hedonisme terkait dengan indikator opinion yaitu pendapat yang berkaitan dengan hal-hal untuk memeroleh kesenangan. Hal ini menunjukkan tingginya hedonisme seorang individu tidak dapat mempengaruhi terjadinya sebuah kecurangan dalam pelaporan keuangan. Hasil penelitian ini sejalan dengan penelitian yang dilakukan oleh Omar et al., (2017); Kassem \& Turksen (2021); Kassem (2018); Najah (2013) yang menyatakan jika para pegawai 
memiliki moralitas yang baik, maka pegawai tersebut tidak akan melakukan tindakan kecurangan, dan Boli (2017) menyatakan sistem pengendalian internal terkait orientasi hedonistik-instrumental berpengaruh negatif terhadap kecurangan melalui moralitas individu. Artinya, semakin efektif sistem pengendalian internal yang disertai dengan meningkatnya moralitas individu, akan mengakibatkan semakin rendah tingkat terjadinya kecurangan dalam pelaporan keuangan.

Keyakinan hukum karma memoderasi pengaruh hedonisme terhadap kecurangan dalam pelaporan keuangan berdasarkan karakteristik responden menunjukan komposisi jenis kelamin didominasi oleh laki-laki sebanyak 65 orang (61,90 persen), dengan usia lebih banyak dibawah $<50$ tahun sebanyak 58 orang (55,23 persen) dan memiliki tingkat pendidikan terbanyak pada sarjana Srata S1 sebanyak 51 orang (48,57 persen). Hal ini mencerminkan bahwa sebagian besar responden memiliki tingkat pendidikan yang cukup baik, yang menandakan bahwa responden memiliki pengetahuan dan kompetensi yang cukup baik pula sehingga niat untuk melakukan tindakan kecurangan dalam pelaporan keuangan tidak akan terjadi. Berdasarkan bukti empiris diperoleh bahwa $\mathrm{H}_{2}$ diterima artinya, keyakinan hukum karma memperlemah pengaruh hedonisme terhadap kecurangan dalam pelaporan keuangan. Ini berarti hedonisme yang berkaitan dengan gaya hidup (kesenangan individu), apabila didukung dengan keyakinan hukum karma tentu akan mempengaruhi seseorang didalam organisasi untuk tidak melalukan tindakan kecurangan dalam pelaporan keuangan. Berdasarkan hasil diatas variabel keyakinan hukum karma merupakan jenis quasi moderasi (moderasi semu).

Hubungan keyakinan hukum karma memoderasi pengaruh hedonisme terhadap kecurangan dalam pelaporan keuangan didasarkan pada Theory of Planned Behavior (TPB), dimana merupakan niat individu untuk melaksanakan perilaku tertentu. Niat diasumsikan untuk menangkap faktor motivasi yang mempengaruhi perilaku, yang mengindikasikan seberapa kuat keinginan orang untuk mencoba, atau seberapa besar usaha yang dilakukan dalam rangka melaksanakan suatu perilaku yaitu perilaku melakukan kecurangan dalam pelaporan keuangan.

Hasil dari tabulasi data penelitian yang menunjukkan jawaban responden yang tinggi pada kuesioner keyakinan hukum karma terkait dengan indikator Konsekunsi yaitu hukuman karena melanggar peraturan dan hukum yang berlaku. Hal ini menunjukkan tingginya keyakinan hukum karma seorang individu tentu akan mempengaruhi seseorang didalam organisasi untuk tidak melalukan tindakan kecurangan dalam pelaporan keuangan.

Hukum karma adalah keyakinan yang dimiliki dan menjadi dasar kehidupan. Menurut hukum karma, tindakan individu dan kolektif menentukan sifat keberadaan di masa kehidupan sekarang atau di masa depan. Semua yang kita lakukan, katakan atau pikirkan, yang akan menimbulkan efek dan pada waktunya akan kembali kepada kita. Filosofi karma mengajarkan kepada kita, tidak sekedar memperhatikan tindakan, tetapi juga pikiran dan emosi kita. Dengan memahami hakekat tentang hukum karma, maka manusia atau individu yang memiliki sifat hedonisme tidak akan mungkin untuk melakukan perbuatanperbuatan tercela seperti melakukan kecurangan yang jelas keluar dari ajaran 
agama dan menyebabkan kerugian atau kehancuran bagi oranglain. Hasil penelitian ini sejalan dengan penelitian yang dilakukan oleh Chadha et al. (2013); Asri (2018); Chakraborty (2014); Hilderbrand (2018).

Berdasarkan hasil penelitian yang dilakukan, hedonisme dan interaksi antara hedonisme dan keyakinan hukum karma berpengaruh terhadap kecurangan dalam pelaporan keuangan. Hal ini berarti terjadinya kecurangan dalam pelaporan keuangan dapat dipengaruhi oleh hedonisme dan keyakinan hukum karma. Dengan adanya keyakinan hukum karma, maka manusia atau individu yang memiliki sifat hedonisme tidak akan mungkin untuk melakukan perbuatan-perbuatan tercela seperti melakukan kecurangan dalam pelaporan keuangan yang jelas keluar dari ajaran agama dan menyebabkan kerugian atau kehancuran bagi orang lain. Berdasarkan hasil penelitian yang dilakukan, implikasi praktis yang dapat diperoleh LPD se-Kota Denpasar adalah keyakinan hukum karma yang tinggi dapat menekan terjadinya kecurangan dalam pelaporan keuangan. Berdasarkan statistik deskriptif pada variabel keyakinan hukum karma menunjukkan terjadinya kecurangan dalam pelaporan keuangan pada LPD se-Kota Denpasar memiliki keyakinan hukum karma yang masih dalam katagori rendah dan dapat ditingkatkan lagi sehingga bisa menekan terjadinya kecurangan dalam pelaporan keuangan.

\section{SIMPULAN}

Berdasarkan hasil pengujian empiris dan pembahasan dapat disimpulkan bahwa hedonisme berpengaruh negatif terhadap kecurangan dalam pelaporan keuangan. Hasil penelitian ini mengindikasikan bahwa hedonisme yang tinggi pada seseorang individu tidak dapat mempengaruhi menurunkan terjadinya sebuah kecurangan dalam pelaporan keuangan. Keyakinan hukum karma memoderasi pengaruh hedonisme terhadap kecurangan artinya, keyakinan hukum karma memperlemah pengaruh hedonisme terhadap kecurangan dalam pelaporan keuangan. Ini berarti hedonisme yang berkaitan dengan gaya hidup (kesenangan individu), apabila didukung dengan keyakinan hukum karma tentu akan mempengaruhi seseorang didalam organisasi untuk tidak melalukan tindakan kecurangan dalam pelaporan keuangan. Penelitian ini memiliki implikasi praktis dan teoritis, implikasi praktis yang dapat diberikan yakni pihak LPD dapat menanamkan pola pikir yang berkaitan dengan hukum karma kepada setiap individu yang bertugas disana sehingga dapat mengurangi timbulnya kecurangan, sedangkan implikasi teoritis dalam penelitian ini yakni penelitian ini dapat menambah ilmu pengetahuan yang berkaitan dengan kecurangan di Lembaga keuangan dan menambah referensi terbaru yang berkaitan dengan fraud triangle theory.

Saran yang dapat diberikan kepada pihak LPD yakni berdasarkan hasil tabulasi data diharapkan masing-masing individu pengurus LPD memiliki sikap dalam mencapai kepuasannya, masing-masing individu pengurus LPD tidak memiliki sikap untuk berusaha menutupi kecuranganya dalam pelaporan keuangan, masing-masing individu pengurus LPD memiliki pola pikir yang berkaitan dengan hukum karma. Penelitian ini memiliki keterbatasan yakni hanya meneliti di LPD Denpasar, Bali dan hanya pada variable yang digunakan pada penelitian ini, sehingga bagi peneliti selanjutnya yang ingin mengambil topik 
serupa dapat menambah variabel independent lainnya yang diindikasikan mempengrauhi kecuarangan dalam pelaporan keuangan, seperti budaya organisasi.

\section{REFERENSI}

Achmad, U. (2019). Dampak Jabatan dalam Memoderasi Pengaruh Tekanan, Peluang dan Rasionalisasi Terhadap Niat Melakukan Fraud: Survei pada Profesi Akuntan. Skripsi. Jakarta: Universitas Islam Negeri Syarif Hidayatullah.

Adinda, Y. M. (2015). Faktor Yang Mempengaruhi Terjadinya Kecurangan (Fraud) Di Sektor Pemerintahan Kabupaten Klaen. Accounting Analysis Journal, 4 (3), 1-9.

Asri, I. A. T. Y. (2018). Belief in the Law of Karma Moderate the Influence of the Tax System on Perceptions of Tax Evasion on Individual Taxpayers in All of the Tax Office Bali Area. International Journal of Sciences: Basic and Applied Research (IJSBAR), 41(1), 39-50.

Aviantara, R. (2021). Scoring the financial distress and the financial statement fraud of Garuda Indonesia with «DDCC» as the financial solutions. Journal of Modelling in Management. https:/ / doi.org/10.1108/JM2-01-2020-0017

Awang, Y., \& Ismail, S. (2018). Determinants of financial reporting fraud intention among accounting practitioners in the banking sector: Malaysian evidence. International Journal of Ethics and Systems, 34(1), 32-54. https:// doi.org/10.1108/IJOES-05-2017-0080

Blickle, G., Schlegel, A., Fassbender, P., \& Klein, U. (2006). Some personality correlates of business white-collar crime. Applied Psychology, 55(2), 220-233. https:// doi.org/10.1111/j.1464-0597.2006.00226.x

Boli, D. (2017). Moralitas Individu Sebagai Pemediasi Pada Pengaruh Sistem Pengendalian Internal Dan Budaya Etis Organisasi Terhadap Fraud. Tesis. Makasar: Universitas Hasanudin Makasar.

Chadha, N., Jain, G., \& Krishnan, V. R. (2013). The Effect of Optimism and Belief in the Law of Karma on Transformational Leadership. International Journal on Vedic Foundations of Management, 1(1), 51-66.

Chakraborty, P. (2014). The Law of Karma and Salvation. International Journal of Humanities \& Social Science Studies, 1(3), 193-195.

Dashtbayaz, M. L., Salehi, M., \& Hedayatzadeh, M. (2022). Comparative analysis of the relationship between internal control weakness and different types of auditor opinions in fraudulent and non-fraudulent firms. Journal of Financial Crime, 29(1), 325-341. https:/ / doi.org/10.1108/JFC-01-2021-0005

Dempere, J., \& Malik, S. (2021). Consumer financial fraud in the United Arab Emirates. Journal of Financial Crime, 28(4). 1193-1209. https://doi.org/10.1108/JFC-11-2020-0229

Hilderbrand, K. M. (2018). Religio-Cultural Factors As Moral Motivation Among Religiously Committed Thai People: A Grounded Theory Study. Journal of Beliefs \& Values, 41(1), 5-19. https:/ / doi.org/10.1080/13617672.2019.1584934

Himmah, E. F. (2013). Persepsi Etis Mahasiswa Akuntansi mengenai Skandal Etis Auditor dan Corporate Manager. Jurnal Akuntansi Multiparadigma, 4(1), 2639. https:// doi.org/10.18202/jamal.2013.04.7180 
Kassem, R. (2018). Exploring external auditors' perceptions of the motivations behind management fraud in Egypt - a mixed methods approach. Managerial Auditing Journal, 33 (1), 16-34. https:/ / doi.org/10.1108/MAJ-11-2016-1470

Kassem, R., \& Turksen, U. (2021). Role of Public Auditors in Fraud Detection: A Critical Review. Contemporary Issues in Public Sector Accounting and Auditing (Contemporary Studies in Economic and Financial Analysis, Vol. 105), Emerald Publishing Limited, Bingley,. 33-56. https://doi.org/10.1108/S1569-375920200000105004

Kennedy, J. P. (2018). Asset misappropriation in small businesses. Journal of Financial Crime. 25 (2), 369-383. https://doi.org/10.1108/JFC-01-2017-0004

Lee, E. Y., \& Ha, W. (2021). Auditors' response to corporate fraud: evidence from audit fees and auditor turnover. Managerial Auditing Journal, 36(3), 405-436. https://doi.org/10.1108/MAJ-12-2019-2515

Liu, H., Yang, B., \& Zhang, J. (2021). Do financial analysts discourage or encourage corporate fraud? Empirical evidence from China. Pacific Accounting Review, 33(1), 81-113. https://doi.org/10.1108/PAR-03-2020-0036

Lotfi, A., Salehi, M., \& Dashtbayaz, M. L (2021). The effect of intellectual capital on fraud in financial statements. The TQM Journal. https:/ / doi.org/10.1108/TQM-11-2020-0257

Munidewi, I. A. B. (2017). Akuntabilitas dalam Perspektif Ajaran Karma Phala Sebagai Pedoman Untuk Membangun Karakter Auditor. Jurnal Ilmiah Akuntansi Dan Bisnis, 12(1), 54-64. https://doi.org/10.24843/jiab.2017.v12.i01.p07

Mustofa, A. (2020). Dijebloskan ke Penjara, Eks Ketua LPD Gerokgak Tak Mau Sendiri di Bui. Retrieved from: https://radarbali.jawapos.com/beritadaerah/radar-buleleng/17/01/2020/dijebloskan-ke-penjara-eks-ketua-lpdgerokgak-tak-mau-sendiri-di-bui, diakses pada November, 2021

Nadzir, M., \& Ingarianti, T. M. (2015). Psychological Meaning of Money dengan Gaya Hidup Hedonis Remaja di Kota Malang. Seminar Psikologi \& Kemanusiaan, 582-596.

Najah, A. F. (2013). Faktor-Faktor yang mempengaruhi Kecenderungan Kecurangan (Fraud): Persepsi Pegawai Dinas Provinsi DIY. Accounting Analysis Journal, 2(3), 259-269.

Norbarani, L. (2012). Pendeteksian Kecurangan Laporan Keuangan Dengan Analisis Fraud Triangle yang Diadopsi dalam SAS No.99. Skripsi. Semarang: Universitas Diponegoro.

Omar, N., Johari, Z. A., \& Smith, M. (2017). Predicting fraudulent financial reporting using artificial neural network. Journal of Financial Crime, 24(2), 362387. https:// doi.org/10.1108/JFC-11-2015-0061

Orth, C. D. O., \& Maçada, A. C. G. (2021). Corporate fraud and relationships: a systematic literature review in the light of research onion. Journal of Financial Crime, 28(3), 741-764. https:/ / doi.org/10.1108/JFC-09-2020-0190

Ozcelik, H. (2020). An Analysis of Fraudulent Financial Reporting Using the Fraud Diamond Theory Perspective: An Empirical Study on the Manufacturing Sector Companies Listed on the Borsa Istanbul. Contemporary Issues in Audit Management and Forensic Accounting (Contemporary Studies in Economic and Financial Analysis, Vol. 102), Emerald Publishing Limited, Bingley, 131- 
153. https://doi.org/10.1108/S1569-375920200000102012

Prastika, E. (2018). Pengaruh Gaya Hidup Hedonisme Terhadap Kecurangan Akademik Mahasiswa Bimbingan dan Konseling. Jurnal Riset Mahasiswa Bimbingan Dan Konseling, 4(6), 251-266.

Price, M., \& Norris, D. M. (2009). White-collar crime: Corporate and securities and commodities fraud. Journal of the American Academy of Psychiatry and the Law, 37(4), 538-544.

Rostami, V., \& Rezaei, L. (2021). Corporate governance and fraudulent financial reporting, Journal of Financial Crime. https://doi.org/10.1108/JFC-07-20210160

Roszkowska, P. (2021). Fintech in financial reporting and audit for fraud prevention and safeguarding equity investments. Journal of Accounting $\mathcal{E}$ Organizational Change, 17(2), 164-196. https://doi.org/10.1108/JAOC-092019-0098

Sallal, F., Velashani, M. A. B, \& Saei, M. J. (2021). Fraudulent financial reporting motivations in emerging markets. Journal of Financial Crime, 28(3), 892-905. https:/ / doi.org/10.1108/JFC-09-2020-0188

Sartika, Y. D., \& Hudainah, H. (2018). Gaya Hidup Hedonis Dan Intensi Korupsi Pada Mahasiswa Pengurus Lembaga Intra Kampus. Jurnal Ilmiah Psikologi Terapan, 6(2), 213-231. https://doi.org/10.22219/jipt.v6i2.7142

Schmidt, M. K., Stowell, N. F., Pacini, C., \& Patterson, G. (2021). Senior financial exploitation through wills, trusts, and guardianship: basics, red flags and prevention measures. Journal of Financial Crime. https://doi.org/10.1108/JFC-10-2021-0225

Shonhadji, N., \& Maulidi, A. (2021). The roles of whistleblowing system and fraud awareness as financial statement fraud deterrent. International Journal of Ethics and Systems, 37(3), 370-389. https:// doi.org/10.1108/IJOES-09-2020-0140

Smaili, N., Arroyo, P., \& Issa, F. A. (2021). The dark side of blockholder control: evidence from financial statement fraud cases. Journal of Financial Crime. https://doi.org/10.1108/JFC-05-2021-0113

Utama, I. G. P. O. S., Ramantha, I. W., Badera, I. D. N. (2018). Analisis Faktor-Faktor Dalam Perspektif Fraud Triangel Sebagai Prediktor Fraudulent Financial Reporting. E-Jurnal Ekonomi Dan Bisnis Universitas Udayana, 7(1), 251-278. https:// doi.org/10.24843/eeb.2018.v07.i01.p09

Venkatesh, V., Morris, M. G., Davis, G. B., \& Davis, F. D. (2003). User Acceptance of Information Technology: Toward a Unified View. MIS Quarterly, 27(3), 425478. https:// doi.org/10.2307/30036540 